\title{
Antipyretic Effect of Cinnamomum burmannii (Nees \& T.Nees) Blume Infusion in Fever-induced Rat Models
}

\author{
Qatrunnada Zainol ${ }^{1}$, Eva M. Hidayat ${ }^{2}$, Stanza Uga Peryoga ${ }^{3}$ \\ ${ }^{1}$ Faculty of Medicine, Universitas Padjadjaran, ${ }^{2}$ Department of Pharmacology and Therapy, Faculty \\ of Medicine, Universitas Padjadjaran, ${ }^{3}$ Department of Child Health, Faculty of Medicine, Universitas \\ Padjadjaran/Dr.Hasan Sadikin General Hospital, Bandung, Indonesia
}

\begin{abstract}
Background : Fever is a frequent clinical sign encountered in human especially in children. Unfortunately, access to health care and medications (antipyretics) are hampered by shortage of services and affordability, which are accentuated by local resources mainly for those living in remote areas. Therefore, using herbal medicineas an alternative in treating fever should be developed as substituent reliance on synthetic antipyretic. This study is conducted to observe antipyretic effect of Cinnamomum burmannii (Nees \& T.Nees) Blume infusion using Diphtheria Tetanus Pertussis (DTP) vaccine-induced fever in rats.

Methods: Twenty-eight male Wistar rats (150 $200 \mathrm{~g}$ ) were randomly allocated into control and treatment groups. Fever was induced with DTP vaccine intramuscularly injected $(0.7 \mathrm{~mL} / 200 \mathrm{~g}$ body weight) and 4 hours later, distilled water $(5 \mathrm{~mL})$ was administered orally to the control group while the treatment group received $5 \mathrm{~mL}$ of $3 \%, 6 \%$, and $12 \%$ of cinnamon infusion. Rectal temperature was measured before the pretreatment, 4 hours after DTP vaccine-induced fever injection and at a 30-minute interval during 180 minutes after the infusion administration. All procedures and protocols were performed in October 2012 at the Pharmacology Laboratory, Faculty of Medicine, Universitas Padjadjaran, Bandung.

Results: Data analysis using the one way analysis of variance (ANOVA) showed significant reduction $(\mathrm{p}<0.001)$ of rectal temperature after 30 minutes and Duncan Post-Hoc test showed significant effect for $6 \%$ and $12 \%$ of cinnamon infusion groups.
\end{abstract}

Conclusion : The antipyretic effect of $6 \%$ and $12 \%$ of Cinnamomum burmannii (Nees \& T.Nees) Blume infusion in fever-induced rat models is found in the first 30 minutes [AMJ.2014;1(1):81-5]

Keywords: Antipyretic, Cinnamomum burmannii (Nees \& T.Nees) Blume, fever, herbal medicine

\section{Efek Antipiretik Infusa Cinnamomum burmannii (Nees \& T.Nees) Blume pada Tikus yang Diinduksi Demam}

Abstrak

Latar belakang: Demam merupakan suatu gejala yang sering muncul terutama pada anak-anak. Antipiretik merupakan obat yang sering digunakan untuk meringankan demam, namun akses kepada pelayanan kesehatan dan pengobatan masih belum terjangkau bagi penduduk yang tinggal di daerah terpencil. Menggunakan herbal sebagai alternatif pengobatan demam harus dikembangkan sebagai substituen terhadap ketergantungan pada obat sintetik. Penelitian ini dilakukan dengan tujuan untuk mengetahui efek antipiretik infusa Cinnamomum burmannii (Nees \& T.Nees) Blume pada tikus yang diinduksi demam menggunakan vaksin Diphtheria Tetanus Pertussis (DTP).

Metode: Penelitian yang dilakukan menggunakan 28 ekor tikus putih jantan galur Wistar yang dikelompokkan secara acak dan diinjeksi dengan vaksin DTP $(0.7 \mathrm{~mL} / 200 \mathrm{~g} \mathrm{BB})$ secara intramuskular untuk menimbulkan demam. Setelah 4 jam, kelompok kontrol diberikan $5 \mathrm{~mL}$ air suling per oral dan kelompok uji diberikan infusa Cinnamomum burmannii (Nees \& T.Nees) Blume per oral dengan dosis masing-masing $3 \% / 5 \mathrm{~mL}, 6 \% / 5 \mathrm{~mL}$ dan 12\%/5 mL. Pengukuran suhu tubuh dilakukan melalui rektal sebelum pemberian vaksin DTP, 4 jam setelah pemberian vaksin DTP dan 30 menit interval setelah perlakuan sampai menit 180. Semua prosedur dan protokol dilaksanakan pada Oktober 2012 di Laboratorium Farmakologi, Fakultas Kedokteran, Universitas Padjadjaran, Bandung.

Hasil: Hasil analisis data menggunakan uji ANOVA menunjukkan penurunan yang signifikan $(p<0.001)$ dari suhu rektal pada menit 30 dan dengan uji Duncan Post-Hoc menunjukkan efek yang signifikan pada kelompok yang diberikan 6\%/5 ml dan 12\%/5 mL infusa Cinnamomum burmannii (Nees \& T.Nees) Blume. Pada menit 60-180 tidak ada penurunan yang signifikan $(\mathrm{p}>0.05)$ dari suhu rektal, dimungkinkan karena

Correspondence: Qatrunnada Zainol, Faculty of Medicine, Universitas Padjadjaran, Jalan Raya Bandung-Sumedang Km.21, Jatinangor, Sumedang, Indonesia, Phone: +6287827699583, Email: qatrunnada25@gmail.com 
durasi kerja yang singkat dari Cinnamomum burmannii (Nees \& T.Nees) Blume.

Simpulan: Efek antipiretik pada pemberian dosis 6\% dan 12\% infusa Cinnamomum burmannii (Nees \& T.Nees) Blume pada tikus yang diinduksi demam ditemukan pada 30 menit pertama. [AMJ.2014;1(1):81-5]

Kata kunci: Antipiretik, Cinnamomum burmannii (Nees \& T.Nees) Blume, demam, pengobatan herbal

\section{Introduction}

Fever is an increase of body temperature due to changes which occur in the body thermoregulatory set-point caused by pyrogens. This is a frequent clinical sign encountered in human, which can be due to infectious or noninfectious diseases. Developing countries such as Indonesia, with high population density and large geographical area, may face disparities in the access to health care and medication due to limited resources, especially for those who live in remote areas where the access to the primary health care (PHC) example such aspusat kesehatan masyarakat (Puskesmas), are still difficult geographically difficult to reach.

Antipyretic side effects such as hypersensitivity, nausea, and vomiting occasionally occur in higher dosage consumption. ${ }^{1}$ Hypersensitivity reactions can be from mild rashes to a more serious problem such as erythema multiforme disorder which is characterized by multiform skin lesions, Stevens-Johnson syndrome (SJS) and toxicepidermal necrolysis (TEN) with promising poor prognosis. ${ }^{2}$

Hence, herbal medicine is a kind of health treatment which we need to look into as an alternative in treating fever since it is relatively affordable and accessible so that we do not have to rely much on synthetic drugs. Cinnamon is one of the examples of herbal medicine that is believed to have many beneficial health effects. With the genus name Cinnamomum belonging to the family Lauraceae, it comprises of many species and one of the species commonly used in Indonesia is Cinnamomum burmannii (Nees \& T.Nees) Blume. ${ }^{3}$

In a pharmacological study, a reduction of body temperature in mice was observed by the administration of decoctions of the dried twigs of cinnamon. ${ }^{4}$ While, an in vitro finding reveals that cinnamaldehyde, a chemical constituent of cinnamon can suppress production of endogenous pyrogens example such as tumor necrosis factor (TNF), interleukin-6 (IL-6), and interleukin-1 (IL-1)5 thus suggesting the role of cinnamaldehyde in providing hypothermic and antipyretic action.

Accordingly, we were interested in conducting a research on Cinnamomum burmannii (Nees \& T. Nees) Blume, using the simplest method of extracting active compounds; infusion, to provide evidence for a potential role of Cinnamomum burmannii (Nees \& T.Nees) Blume in the treatment of fever.

\section{Methods}

A total of 28 male Wistar rats (150-200 g) obtained from Pusat Penelitian Antar Universitas (PPAU), Institute of Technology, Bandung were used in this research. The rats were housed at the animal facility of the Pharmacology Laboratory, Faculty of Medicine, Universitas Padjadjaran, Bandung with standard condition of temperature $(25 \pm$ $2^{\circ} \mathrm{C}$ ). Rats that have been used previously on other studies were excluded. Seven days prior to starting of the experiment, the rats were kept under laboratory conditions and allowed unlimited food and water The rats were sacrificed with formalin injection at the end of experiment. Seven rats were used in each intervention group. The research protocols and animal care procedure were approved by the Health Research Ethics Committee of the Faculty of Medicine, Universitas Padjadjaran, Bandung.

The Cinnamomum burmannii (Nees \& T.Nees) Blume originates from Padang, Indonesia was bought from a herbal store in October 2012. The sample was identified as Cinnamomum burmannii (Nees \& T.Nees) Blume by the Laboratory of Plant Taxonomy, Biology Department, Faculty of Mathematics and Natural Sciences, Universitas Padjadjaran. The cinnamon barks were measured into suitable weight of $0.15 \mathrm{~g}, 0.30 \mathrm{~g}$ and $0.60 \mathrm{~g}$. Water is heated in the first level pot until it is boiled and cinnamon barks mixed with $5 \mathrm{~mL}$ of water were placed at the second level pot, heated until $90^{\circ} \mathrm{C}$ for 15 minutes with every 5 minutes the preparation is 
stirred. The preparation was then filtered using a flannel cloth and adding hot water through the pulp until the needed volume was obtained. The filtrate had a brown to dark brown colour varying according to the different concentrations. Herbal infusion of Cinnamomum burmannii (Nees \& T.Nees) Blume was kept in a container until the time of treatment.

Twenty-eight male Wistar rats $(150200$ g) were randomly allocated into 4 groups. The normal body temperature of each rat was measured rectally at predetermined intervals and recorded. The rectal temperature was measured by gently inserting a digital thermometer to a length of approximately $2.5 \mathrm{~cm}$ intra rectal until stable reading was obtained or for up to $3060 \mathrm{~s}$. For this, rats were restrained manually at the base of the tail. The accuracy of the thermometer was accurate to $0.1^{\circ} \mathrm{C}$. After measuring basal rectal temperature, animals were injected intramuscularly with $0.7 \mathrm{~mL} / 200 \mathrm{~g}$ body weight of DTP vaccine. Rats were then returned to their housing cages.

Four hours after DTP vaccine injection, the rat's rectal temperature was measured again, as described previously. Only rats that showed an increase in temperature of at least $0.5^{\circ} \mathrm{C}$ were used for this study. The cinnamon infusion with doses of $3 \%, 6 \%$ and $12 \%$ were administered $5 \mathrm{~mL}$ orally to 3 groups of animals. The control group received $5 \mathrm{~mL}$ of distilled water orally. Rectal temperature was measured at 30 minutes intervals during a period of 180 minutes after the infusion and distilled water administration.

Difference in mean values between groups were analyzed for each 30 minutes interval by a one way analysis of variance (ANOVA) followed by Duncan post-hoc test. Statistical significance was assessed as $\mathrm{p}<0.05$.

\section{Results}

Results of the antipyretic effect of the Cinnamomum burmannii (Nees \& T.Nees) Blume infusion are presented in Figure 1. Thirty minutes after intervention $\left(30^{\prime}\right)$ an increase of rectal temperature by $0.5^{\circ} \mathrm{C}$ was observed in control animals which were given distilled water producing a mean rectal temperature of $38.24 \pm 0.24^{\circ} \mathrm{C}$.

Treatment with $5 \mathrm{~mL}$ of $6 \%$ (group 3) and $12 \%$ (group 4) cinnamon infusion significantly $(p<0.001)$ reduced fever induced by DTP vaccine at 30 minutes after oral

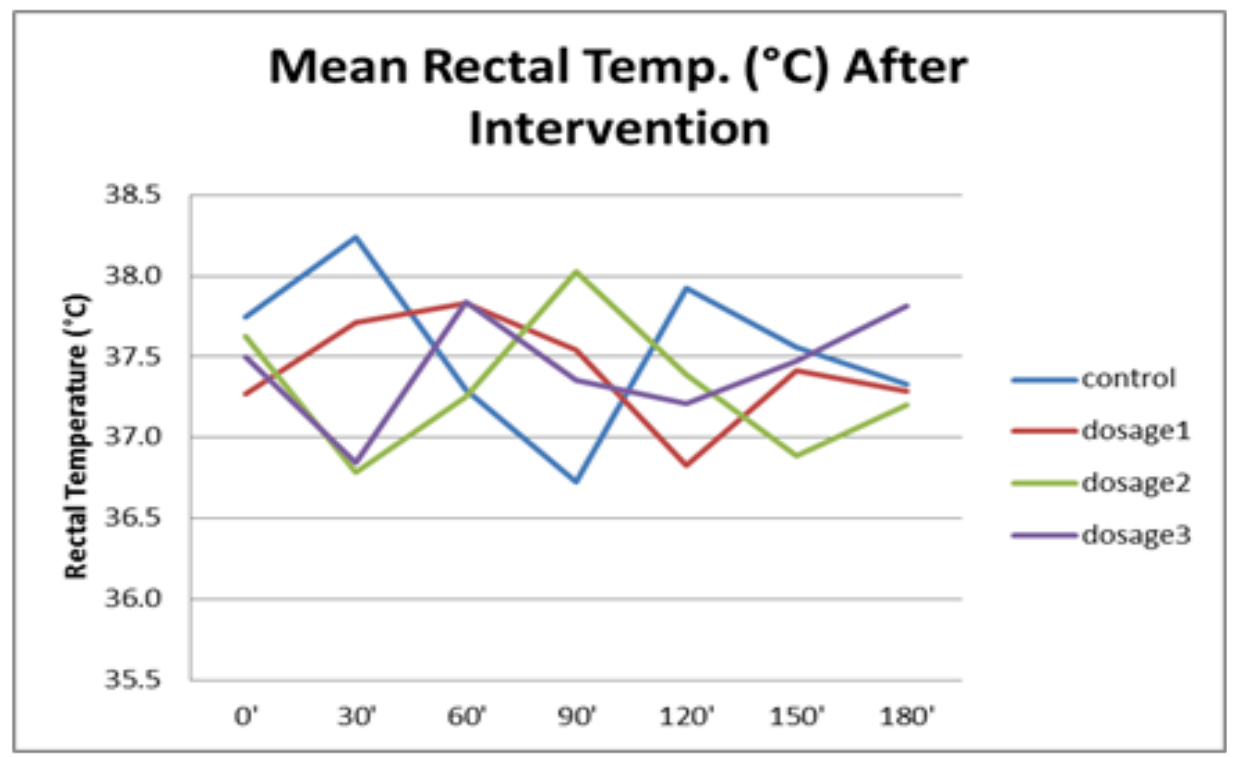

Figure 1 Change in rectal temperature after intramuscular injection of vaccine DTP, oral administration of $5 \mathrm{ml}$ distilled water and 3 doses of Cinnamomum burmannii infusion to rats with fever. All drugs were administered at 0 minutes $\left(0^{\prime}\right), n=7$ for all groups 
administration by approximately $0.8^{\circ} \mathrm{C}$. On the other hand, treatment with $5 \mathrm{~mL}$ of $3 \%$ cinnamon infusion (group 2) failed to reduce the temperature where it increased the rectal temperature by $0.4^{\circ} \mathrm{C}$, slightly lower by $0.1^{\circ} \mathrm{C}$ as compared to the control group at 30 minutes after oral administration.

The antipyretic effects of 2 doses of Cinnamomum burmannii (Nees \& T.Nees) Blume were noted as early as 30 minutes after oral administration and the effect was not maintained for the next 30 minutes until 180 minutes after oral administration. There were fluctuant temperature values with no exact increasing or decreasing trend. Rectal temperature of the entire group did not reduce to normal temperature at 180 minutes after oral administration.

\section{Discussion}

Theoretically, antipyretic acts works as an inhibitor on prostaglandin synthesis by inhibiting the enzyme cyclooxygenase (COX). Cyclooxygenase enzyme is also influenced by the presence of cytokines such as tumor necrosis factor- $\alpha$ (TNF- $\alpha$ ), interleukin-6 (IL-6), interleukin-1 (IL-1) and interferon- $\gamma$ produced by monocytes and macrophage. Meanwhile, monocytes and macrophage are stimulated by exogenous pyrogens when the body encounters with infection, toxins, or injury. In the absence of COX enzyme, arachidonic acid cannot be converted to prostaglandin (PGH2) hence no other prostaglandin as mediators of fever can be yield. ${ }^{6}$

Diptheria Tetanus Pertussis (DTP) vaccine used in this research to induce fever in the rats was a combination of vaccine against infection of diphtheria, pertussis and tetanus. It is believed to have cause pyrogenic activity due to pertussis component in the vaccine in which the toxins presence in vaccine indirectly serves as exogenous pyrogens that cause fever. $^{7}$

The antipyretic effect of cinnamon might be due to cinnamaldehyde content that may have inhibitory effect on secretion of IL-1 and then prostaglandin synthesis. This correspond to a study conducted by agroup of researchers from Taiwan who reveal that cinnamaldehyde can suppress production of endogenous pyrogens (TNF, IL-6, and IL-1). ${ }^{5}$ The antipyretic effect of Cinnamomum burmannii (Nees \& T.Nees) Blume may be due to these properties which influence in the chain breaking and prevention of prostaglandin release that cause fever.
Lower doses of Cinnamomum burmannii (Nees \& T. Nees) Blume infusion had less efficacy in reducing rectal temperature. Increase in temperature at minutes 60 and not reaching basal temperature could be due to shorter duration of action of cinnamon in decreasing the high temperature. Whether returning to thermal regulatory set point to normal is due to persistent exist of endogenous pyrogens in the circulation for several hours. ${ }^{8}$

Cinnamaldehyde, a chemical constituent of cinnamon which has inhibitory effect on secretion of endogenous pyrogen may not be sufficient enough to fully inhibit release of endogenous pyrogens, COX and the prostaglandins. Therefore, a further research should be conducted on Cinnamomum burmannii (Nees \& T. Nees) Blume using other methods of extracting the active compound which possibly result in higher concentration of cinnamaldehyde, thus will increases its effectiveness.

For the control group, the decrease in temperatureafter 180 minutes can be explained since probably rats, as well as humans have their own mechanism in regulating body temperature. One of the ways is using their tail as thermoregulatory functions by dilating their tail blood vessel. ${ }^{9}$

It can be concluded that $5 \mathrm{~mL}$ of $6 \%$ and $12 \%$ Cinnamomum burmannii (Nees \& T.Nees) Blume infusion per oral had antipyretic effect for the first 30 minutes. Additional studies are needed to determine if the antipyretics effects of cinnamon were due to inhibitory effect of cinnamaldehyde on secretion of endogenous pyrogens, and compared with gold standard antipyretics example paracetamol to see whether there was a significant difference in antipyretic effect between cinnamon and paracetamol. The research also should be developed into clinical trial and lastly expanded into phytopharmaca.

\section{References}

1. Annette OP. OTC pain relievers and fever reducers [cited 2012 April 27]. Available from: http://www.medicinenet.com/ analgesics_antipyretics/page4.htm.

2. Lazar AJF, Murphy GF. The skin. In: Kumar V, Abbas AK, Aster Jon K: editors. Robbins and Cotran pathologic basis of disease. 8ed.Philadelphia: Saunders Elsevier; 2010. p. 1189-91

3. Katzer G. Indonesian Cinnamon (Cinnamomum burmannii (Nees \& T.Nees) 
Blume[Nees \& T. Nees] Blume). [cited 2012 April 29]. Available from: http:// www.unigraz.at/ katzer/engl/Cinn_bur. html\# const.

4. Thampuran RA, Vijayan K. Pharmacology and Toxicology of Cinnamon and Cassia. Boca Raton: CRC Press; 2003.

5. Chao LK, Hua KF, Hsu HY, Cheng SS, Lin IF, Chen CJ, et al. Cinnamaldehyde inhibits pro-inflammatory cytokines secretion from monocytes/macrophages through suppression of intracellular signaling. Food Chem Toxicol. 2008;46(1):220-31

6. Kumar, Abbas, Fausto, Aster. Mediators of inflammation. Robbins and Cotran Pathologic Basis of Disease. Philadelphia: Saunders Elsevier; 2010.

7. Centers for Disesae Control and Prevention (CDC). Vaccine information statement. [cited n 2012 April 30]. Available from: http://www.cdc.gov/vaccines/pubs/vis/ downloads/vis-dtap.pdf.

8. Netea MG, Kullberg BJ , Van der Meer JWM. Circulating cytokines as mediators of fever. Clin Infect Dis. 2000;31 Suppl 5:S178-84.

9. Hanson A. The Rat's tail. [cited 2012 November 15]. Available from: http:// www.ratbehavior.org/RatTails.htm. 